\title{
Perilaku Struktur Jembatan Baja Pelengkung Berdasarkan Spektrum Gempa
}

\author{
Behavior of Curved Steel Bridge Structures Based on Earthquake Spectrum
}

\author{
Widya Apriani ${ }^{1, *}$, Fadrizal Lubis ${ }^{1}$, Reni Suryanita ${ }^{2}$, Elva Nidya Sari ${ }^{1}$ \\ 1Jurusan Teknik Sipil, Fakultas Teknik Universitas Lancang Kuning, Jl. Yos Sudarso Km. 8 Pekanbaru, Riau \\ ${ }^{2} J u r u s a n$ Teknik Sipil, Fakultas Teknik Universitas Riau, Jl. HR Soebrantas KM.12.5 Pekanbaru, Riau
}

\author{
* Penulis korespondensi : widyaapriani@unilak.ac.id \\ Tel.: +62-85271620554; fax.: - \\ Diterima: 14 Oktober 2019; Direvisi: 21 Oktober 2019; Disetujui: 23 Oktober 2019. \\ DOI: 10.25299/saintis.2019.vol19(02).3924
}

\section{Abstrak}

Perencanaan struktur jembatan baja pelengkung harus memperhatikan kemampuan respon strukturnya yang rentan terhadap deteriorasi akibat fatik, ancaman gempa bumi kuat atau angin topan, khususnya diwilayah sumatera yang mempunyai resiko gempa yang tinggi. Penelitian ini fokus memprediksi struktur jembatan pelengkung baja dengan analisis repons spectra dengan bantuan software analisis struktur gempa berdasarkan SNI 1726-2012 m. Percepatan gempa yang diambil berasal dari beberapa kota seperti Kota Aceh, Padang, Tanjung Pinang, dan Pekanbaru yang memliki karakteristik. Hasil analisis menunjukkan respon struktur jembatan terbesar terjadi di Padang dengan nilai perpindahan sebesar 0,016267 m dan percepatan sebesar 0,0235 m. Sementara itu, respons struktur terkecil terjadi di kota tanjung pinang dengan nilai perpindahan sebesar 0,01552 m dan nilai percepatan sebesar 0,0208 m. Diharapkan dengan diketahuinya hasil prediksi kesehatan struktur jembatan dapat digunakan sebagai referensi/masukan bagi pemerintah dan pihak yang terkait dalam usaha memperbaiki jembatan dengan tepat, sehingga diharapkan dapat mencegah terjadinya keruntuhan struktur jembatan.

Kata Kunci: Jembatan baja pelengkung, respons struktur, spektra gempa sumatera.

\section{Abstract}

Curved steel bridge structure planning must pay attention to the responsiveness of the structure that is vulnerable to deterioration due to fatigue, the threat of strong earthquakes or hurricanes, especially in the region of Sumatra which has a high earthquake risk. This study focuses on predicting the structure of steel curved bridges with spectral response analysis with the help of earthquake structure analysis software based on SNI 1726-2012. The earthquake acceleration taken came from several cities such as Aceh City, Padang, Tanjung Pinang, and Pekanbaru which have characteristics. The analysis shows the largest bridge structure response occurred in Padang with a displacement value of 0.016267 and acceleration of 0.0235. Meanwhile, the smallest structural response occurred in Tanjung Pinang city with a displacement value of 0.01552 and an acceleration value of 0.0208. It is expected that by knowing the results of the bridge structure health predictions can be used as a reference / input for the government and related parties in an effort to repair the bridge appropriately, so that it is expected to prevent the collapse of the bridge structure.

Keywords: Curved steel bridge, structural response, Sumatra earthquakes spectra.

\section{PENDAHULUAN}

Perencanaan struktur jembatan harus memperhatikan respon strukturnya terhadap lingkungan seperti ancaman gempa bumi yang kuat, atau angin topan karena struktur jembatan rentan terhadap kerusakan dan deteriorasi selama masa layan [1].

Jembatan baja pelengkung merupakan salah satu tipe jembatan dengan tipe struktur rangka yang membentuk kurva lengkung kemudian disatukan dengan hanger/kabel baja sebagai penyalur beban lantai jembatan menuju ke tumpuan jembatan[2]. Jembatan ini merupakan jembatan yang terdiri dari berbagai jenis material penyusun seperti beton bertulang, baja pelengkung, kayu.
Konstruksi Jembatan pelengkung memiliki keunggulan antara lain bentuk jembatan pelengkung merupakan inovasi dari peradaban manusia yang memiliki nilai estetika tinggi dan memiliki kekuatan yang tinggi terbukti jembatan kuno Romawi menggunakan tipe ini dan masih berdiri hingga kini. Namun konstruksi rangka baja ini memiliki kelemahan khususnya pada biaya pemeliharaan dan juga rentan terhadap resiko yang dapat mengakibatkan strukturnya menekuk. Bukan hanya itu, konsentrasi tegangan yang terlalu tinggi juga bisa menjadikan baja kehilangan daktilitasnya [3]. Oleh karena itu perlu adanya monitoring struktur sebelum kegagalan bencana terjadi, salah satunya yaitu dengan analisis respon spectrum [4]. Tujuan penelitian ini difokuskan 
untuk menentukan respons spektrum jembatan berupa nilai perpindahan struktur dan nilai percepatan struktur akibat pengaruh lokasi dan jenis tanah yang berbeda (3 jenis tanah: tanah lunak, tanah sedang dan tanah keras). Dalam menganalisis repsons spketrum, di ambil wilayah sumatera yaitu kota padang, aceh, tanjung pinang dan pekanbaru sebagai pembanding kekuatan struktur jembatan tersebut.

Terdapat beberapa metode dalam menganalisis beban gempa antara lain metode static ekuivalen, metode dinamik respon sspektrum dan metode analisis dinamik nonlinier time history [5]. Analisis dinamik memiliki keunggulan dibandingkan dengan analisis static yang hanya terbatas oleh bentuk konfigurasi ruang dan ketinggian bangunan. Analisis resposn spektrum merupakan analisis dinamik yang dapat menunjukkan kondisi respons struktur menurut waktu puncak dari percepatan gempa. Respons spektrum adalah grafik yang menyatakan hubungan antara periode getar struktur ( $\mathrm{T}$ ) dengan respons struktur maksimum saat mengalami getaran gempa tertentu[6].

\section{METODOLOGI}

Respons spektrum merupakan sutu spektrum hasil analisis dinamik beban gempa yang mengambil titik-titik maksimum dari respons gempa dalam hubungan periode dengan respons sturktur yang dinyatakan dalam suatu grafik[7].

Prosedur untuk memperoleh grafik respons spektrum gempa adalah sebagai berikut.

1. Menentukan nilai spectral percepatan pada 0,2 detik $\left(S_{s}\right)$ dan spectral percepatan pada 1 detik $\left(\mathrm{S}_{1}\right)$

2. Menetukan Koefisien Situs (Fa dan Fv)

Nilai Fa dan Fv ditentukan berdasarkan kelas situs tanah yaitu SA (batuan keras), SB (Batuan), SC (Tanah keras, sangat padat dan batuan lunak), SD (tanah sedang), SE (Tanah lunak), dan SF.

Menentukan Koefisien situs (Fa)

Tabel 1. Koefisien Situs Fa

\begin{tabular}{|c|c|c|c|c|}
\hline \multirow{4}{*}{$\begin{array}{l}\text { Kelas } \\
\text { situs }\end{array}$} & \multicolumn{4}{|c|}{ Parameter Respons Spektral Percepatan } \\
\hline & \multirow{2}{*}{\multicolumn{4}{|c|}{$\begin{array}{l}\text { Gempa MCER terpetakan pada Periode } \\
\text { Pendek, } T=0,2 \text { detik, } S_{s}\end{array}$}} \\
\hline & & & & \\
\hline & $S_{s} \leq 0,25$ & $S_{s}=0.5$ & $S_{s}=0.75$ & $S_{s}=1$ \\
\hline SA & 0.8 & 0.8 & 0.8 & 0.8 \\
\hline SB & 1.0 & 1 & 1 & 1.0 \\
\hline $\mathrm{SC}$ & 1.2 & 1.2 & 1.1 & 1.0 \\
\hline SD & 1.6 & 1.4 & 1.2 & 1.1 \\
\hline SE & 2.5 & 1.7 & 1.2 & 0.9 \\
\hline
\end{tabular}

Catatan : Untuk nilai-nilai antara Ss dilakukan interpolasi linier

Menentukan koefisien situs (Fv)

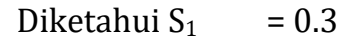

Tabel 2. Koefisien Situs Fv

\begin{tabular}{|c|c|c|c|c|c|}
\hline \multirow{3}{*}{$\begin{array}{l}\text { Kelas } \\
\text { situs }\end{array}$} & \multicolumn{5}{|c|}{ Parameter Respons Spektral Percepatan } \\
\hline & $\begin{array}{l}\text { Gempa } \\
\text { detik, } S_{1}\end{array}$ & MCER & petakan & bada $P$ & ioda 1 \\
\hline & $S_{1} \leq 0.1$ & $S_{1}=0.2$ & $S_{1}=0.3$ & $S_{1}=0.4$ & $S_{1} \geq 0.5$ \\
\hline SA & 0.8 & 0.8 & 0.8 & 0.8 & 0.8 \\
\hline SB & 1.0 & 1 & 1 & 1.0 & 1.0 \\
\hline $\mathrm{SC}$ & 1.7 & 1.6 & 1.5 & 1.4 & 1.3 \\
\hline SD & 2.4 & 2 & 1.8 & 1.6 & 1.5 \\
\hline SE & 3.5 & 3.2 & 2.8 & 2.4 & 2.4 \\
\hline
\end{tabular}

Catatan : Untuk nilai-nilai antara Ss dilakukan interpolasi linier

3. Menentukan Spektral Respons Percepatan (Spectral Response Acceleration) $\mathrm{S}_{\mathrm{DS}}$ dan $\mathrm{S}_{\mathrm{D} 1}$ untuk

$$
\begin{aligned}
& \mathrm{S}_{\mathrm{MS}}=\mathrm{SS} \times \mathrm{Fa} \\
& \mathrm{S}_{\mathrm{M} 1}=\mathrm{S}_{1} \times \mathrm{F}_{\mathrm{v}} \\
& \mathrm{S}_{\mathrm{DS}}=\frac{2}{3} \times \mathrm{S}_{\mathrm{MS}} \\
& \mathrm{S}_{\mathrm{D} 1}=\frac{2}{3} \times \mathrm{S}_{\mathrm{M} 1}
\end{aligned}
$$

4. Menghitung parameter respons spectrum desain

$$
\begin{aligned}
& T_{0}=0,2 \times \frac{S_{\mathrm{D} 1}}{\mathrm{~S}_{\mathrm{DS}}} \\
& \mathrm{TS}=\frac{\mathrm{S}_{\mathrm{D} 1}}{\mathrm{~S}_{\mathrm{DS}}}
\end{aligned}
$$

Untuk periode yang lebih kecil dari , spectrum respons percepatan desain, Sa, harus diambil dari persamaan[7] :

$$
S_{a}=S_{D S}\left(0.4+0.6 \frac{T}{T_{0}}\right)
$$

Untuk periode yang lebih besar dari Ts, Sa berdasarkan persamaan [8]:

$$
S_{a}=\frac{S_{D 1}}{T}
$$

Diperoleh grafik respons spektrum:

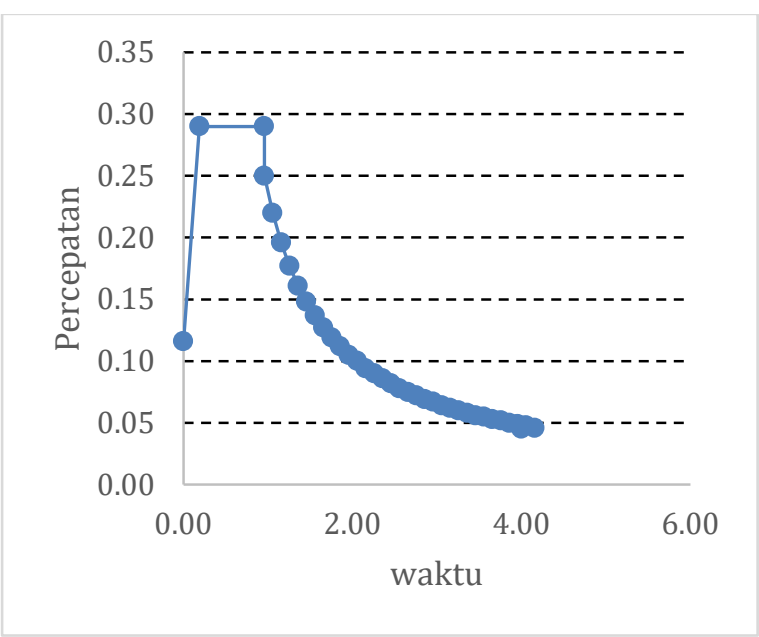

Gambar 1. Respons Spekta Pekanbaru 


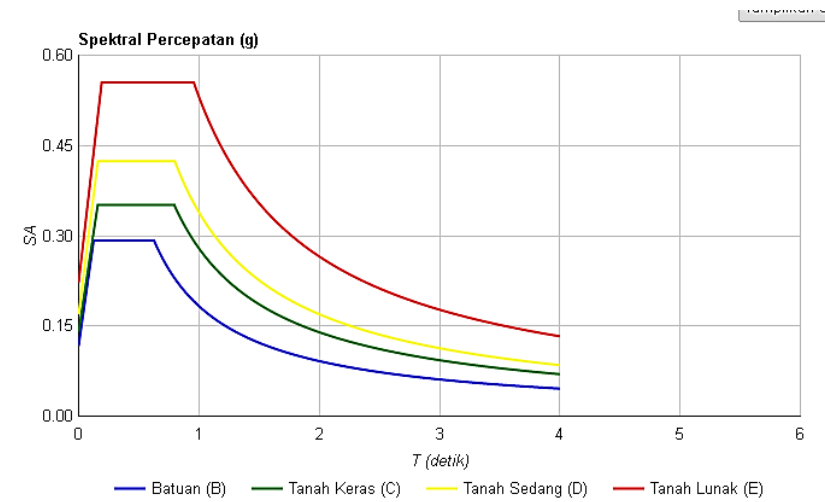

Gambar 2. Input Data Response Spectrum Gempa Pekanbaru

Selanjutnya ahap analisis jembatan dilakukan dengan menggunakan bantuan software struktur elemen hingga. Adapaun respons yang akan ditinjau adalah perpindahan dan percepatan struktu jembatan[9]. Tahap awal pemodelan jembatan dilakukan dengan mendefinisikan materal dan jenis penampang setiap elemen jembatan.

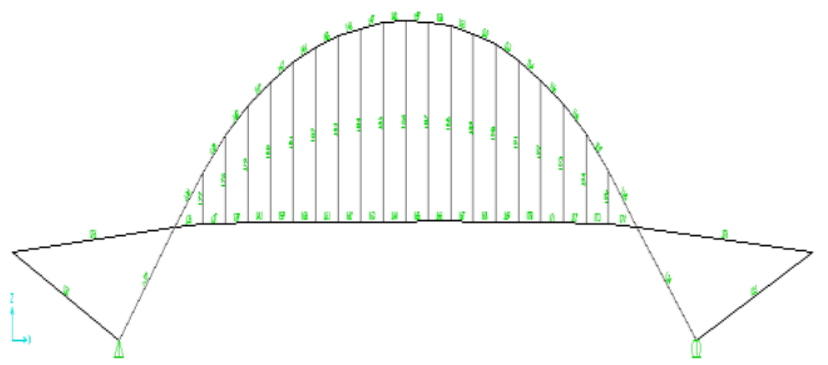

Gambar 3. longitudinal cross section Jembatan Pelengkung

Section properties jembatan yang digunakan pada penelitian ini antara lain:

1. Tipe konstruksi $=$ Baja pelengkung

2. Diameter hanger $=10 \mathrm{~cm}$

3. Lebar jalan $=7 \mathrm{~m}$

4. Lebar bahu=1,6 m

5. Lebar jembatan seluruhnya $=10.2 \mathrm{~m}$

6. Rangka pelengkung $=120 \times 80 \mathrm{~cm} \mathrm{t} 24 \mathrm{~mm}$

7. Rangka bawah $=60 \times 60 \mathrm{~cm} \mathrm{t} 24 \mathrm{~mm}$

8. Diafragma $=400 \times 400 \mathrm{~cm}$

9. Girder $=600 \times 600 \mathrm{~cm}$

10. Baja mutu = JIS G 3106 SM YB

11. Tegangan leleh (fy) $=295 \mathrm{Mpa}$

12. Tegangan putus/ultimate $(\mathrm{fu})=490 \mathrm{Mpa}$

13. Modulus elastisitas $200000 \mathrm{Mpa}$

14. Berat jenis $=78.5 \mathrm{kN} / \mathrm{m}^{3}$

15. Baja mutu Grade $=490 \mathrm{MPa}$

16. Tegangan leleh $=490 \mathrm{MPa}$

17. Tegangan putus $=610 \mathrm{MPa}$

18. Modulus elastis $=210000 \mathrm{MPa}$

19. Berat jenis $=78.5 \mathrm{kN} / \mathrm{m}^{3}$
Tahapan selanjutnya yaitu membuat komponen gelagar, diafragma, dan perletakan jembatan. Setelah itu dilakukan penginputan beban jembatan seperti beban mati, beban lalu lintas dan beban gempa berupa respons spectrum untuk masing masing lokasi[10]. Perhitungan pembebanan digunakan untuk menentukan beban yang bekerja di jembatan. Beban yang dimasukkan sesuai dengan standar SNI Pembebanan jembatan tahun 2016[11][12]. Berat sendiri struktur jembatan dihitung secara otomatis oleh SAP 2000[13]. Adapun beban berat sendiri yang diperhitungkan antara lain:

1. Beban Tetap Berat sendiri, terdiri atas:

- Berat sendiri baja $=7850 \mathrm{~kg} / \mathrm{m}^{3}$ $\left(78 \mathrm{kN} / \mathrm{m}^{3}\right)$

- Berat sendiri beton (deck slab) = 2400 $\mathrm{kg} / \mathrm{m}^{3}\left(24 \mathrm{kN} / \mathrm{m}^{3}\right)$

Kedua beban diatas didefinisikan langsung oleh program SAP2000.

- Berat sendiri trotoar (beton) $=2400$ $\mathrm{kg} / \mathrm{m}^{3}\left(24 \mathrm{kN} / \mathrm{m}^{3}\right)$

- Berat aspal beton $=2240 \mathrm{~kg} / \mathrm{m}^{3}$ $\left(22 \mathrm{kN} / \mathrm{m}^{3}\right)$

a. lantai

luas lantai $=0.5(0.1 \mathrm{~m}+0.13 \mathrm{~m}) \times 11 \mathrm{~m}=$ $1.265 \mathrm{~m}^{2}$

total berat $=1.265 \mathrm{~m}^{2} \times(98 / 20) \times 24 \mathrm{kN} / \mathrm{m}^{3}$ $=148.764 \mathrm{kN}$

b. balok memanjang

total panjang balok $=4.9 \mathrm{~m}$

luas balok hollow 400 x $600=78 \mathrm{kN} / \mathrm{m}^{3} \mathrm{x}$ $0.2352 \mathrm{~m}^{3}=18.346 \mathrm{kN}$

total berat balok memanjang $=18.346 \mathrm{kN}$

2. Beban kerb dan railing

Beban trotoar dan lapisan aspal beton merupakan beban mati sekunder/ tambahan (super impose dead load) yang beratnya tetap namun dapat berubah selama masa layan jembatan[13][14], dan diperhitungkan sebagai input beban dalam SAP2000.

- Beban trotoar $=0.2 \mathrm{~m} \times 24 \mathrm{kN} / \mathrm{m}^{3}=4.8$ $\mathrm{kN} / \mathrm{m}^{2}$

Trotoar disepanjang bentang pada dua sisi jembatan dengan lebar 1,5 meter dan bekerja sebagai beban merata area.

- Beban railing $=0.5 \times 0.8 \mathrm{~m} \times(0.25+$ $0.15) \mathrm{m} \times 24 \mathrm{kN} / \mathrm{m} 3=3.84 \mathrm{kN} / \mathrm{m}$

Railing berada di sepanjang bentang pada kedua sisi jembatan dan bekerja sebagai beban garis merata[15].

Total Berat $=2$ ( kanan dan kiri) $\times 3.84 \mathrm{kN} / \mathrm{m}$ $\mathrm{x} 4.9 \mathrm{~m}=37.632 \mathrm{kN}$

Sedangkan beban mati tambahan dihitung dengan BTR $=9,0\left(0,5+\frac{15}{160}\right)=5.34375 \mathrm{kN} / \mathrm{m} 2$ dan beban garis terpusat yang digunakan adalah $49 \mathrm{kN} / \mathrm{m}$ dengan faktor pembesaran dinamis 1,375. Berat truk uji dan penempatan beban truk 
uji disesuaikan dengan kondisi pada saat pengujian beba[16][17][18].

Selanjutnya dilakukan analisis respons spectrum dengan melihat ragam komulatif dengan partisipasi lebih dari 90\%[19][20]. Selanjunya di analaisis nilai perpindahan dan percepatan untuk arah x dana rah y[21].

\section{HASIL DAN DISKUSI}

Sesuai SNI 1726-2012 jumlah pola getar yang ditinjau dalam penjumlahan respon ragam mencakup partisipasi sekurang kurangnya 90\%[22][23]. Ragam getar struktur yang diperoleh digunakan untuk menentukan karakteristik dinamik dari suatu system strktur. Ragam getar ini didefinisikan oleh properti fisik serta distribusi spasial dari komponen penyusun system struktur[24]. Dari hasil diperoleh ragam pada mode pertama hingga ketiga adalah linier dengan partisipasi massa sebesar 90\%.. Dalam analisis dinamik yang dilakukan, digunakan 15 ragam pola getar dan patisipasi massa yang disumbangkan masing-masing $90.22 \%$ pada mode ke 8 untuk translasi arah x (SUM UX), sebesar 92.79\% pada mode ke 14 untuk translasi arah y (SUM UY) dan sebesar $93.55 \%$ pada mode ke 9 untuk rotasi arah sumbu z (SUM RZ).

Berdasarakan gambar 4 diketahui perioda fundamental $\mathrm{T}$ sebesar 1,61345 det dan frekuenis $\mathrm{f}$ sebesar 0,61979 Hz. Titik pengamatan dilakukan pada tengah jembatan (nodal 234) yang merupakan titik maksimum displacementnya (Gambar 4).

Hasil analisis respon struktur berupa perpindahan perpindahan dan percepatan untuk tinjauan 4 lokasi diwilayah sumatera yang memiliki kondisi gempa dan kondisi tanah yang berbedabeda. Titik tinjauan dapat dilihat pada gambar berikut ini.

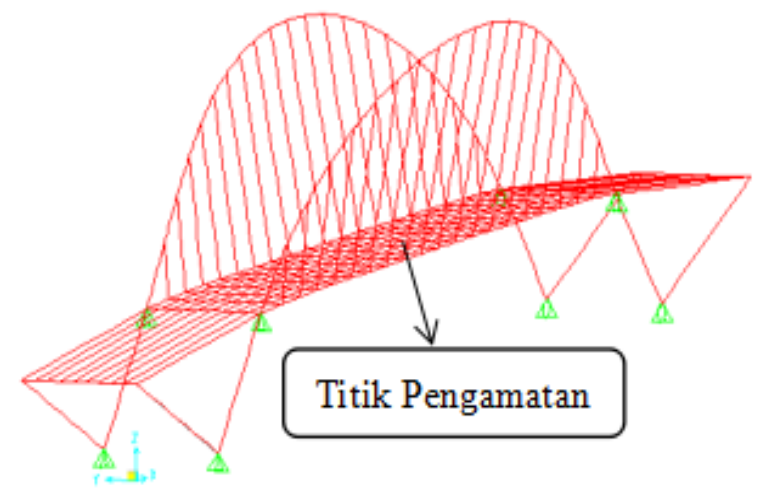

Gambar 4. Titik Pengamatan
Ragam ke-1 $(\mathrm{T}=1,61345$ det; $\mathrm{f}=0,61979 \mathrm{~Hz})$

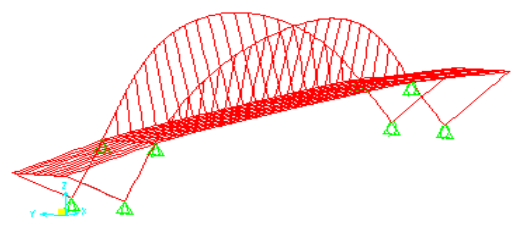

Ragam ke-2 $(\mathrm{T}=1,59641 \mathrm{det} ; \mathrm{f}=0,62641 \mathrm{~Hz})$

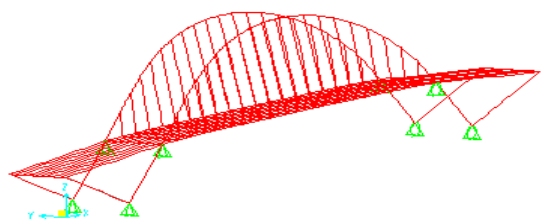

Ragam ke-3 ( $\mathrm{T}=1,31245$ det; $\mathrm{f}=0,76193 \mathrm{~Hz})$

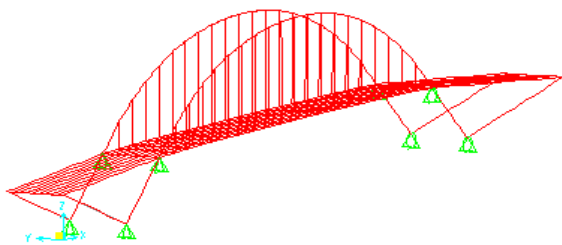

Ragam ke-4 ( $\mathrm{T}=1,09848$ det; $\mathrm{f}=$ 0,91035 Hz)

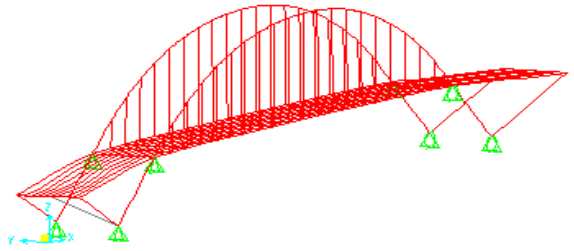

Ragam ke-4 ( $\mathrm{T}=1,09848$ det; $\mathrm{f}=$ 0,91035 Hz)

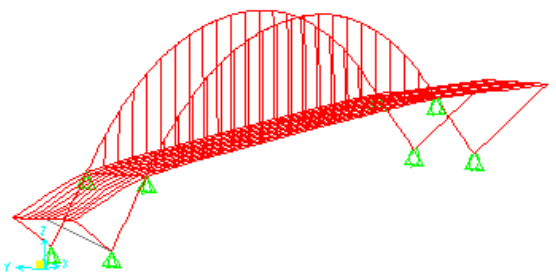

Ragam ke-5 ( $\mathrm{T}=$ 0,81380 det; $\mathrm{f}=1,22880 \mathrm{~Hz})$

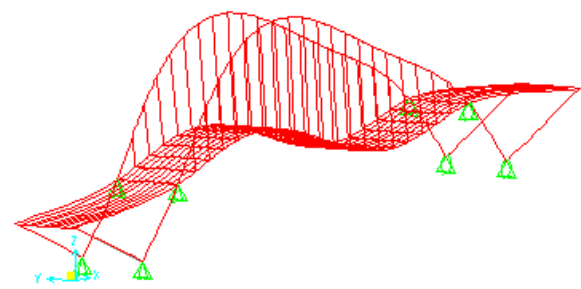




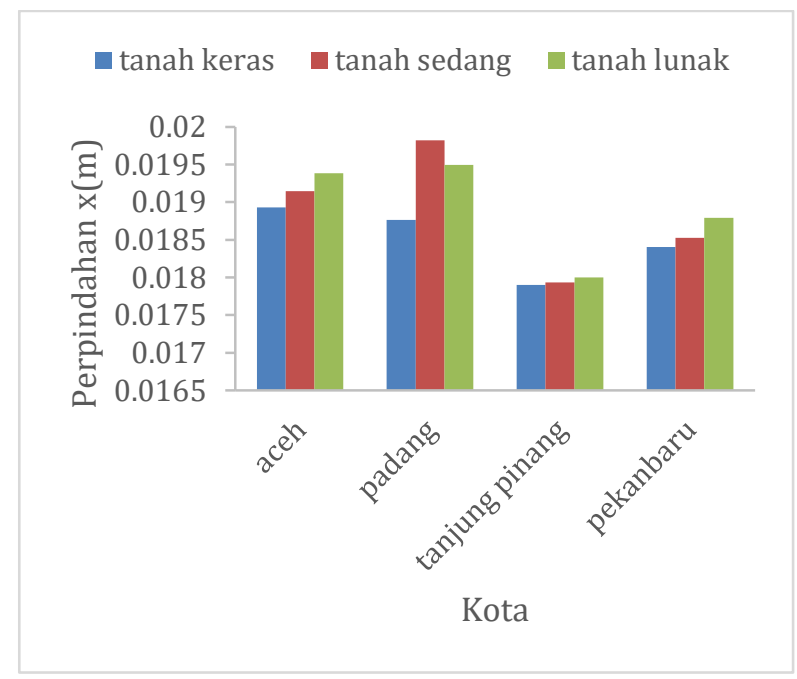

Gambar 5. Perpindahan Arah X Pada Titik Pengamatan

Berdasarkan gambar 5 wilayah padang memiliki nilai perpindahan tertinggi yaitu 0,019822 $m$ dengan kondisi tanah sedang kemudian diikuti dengan tanah lunak. Sementara nilai perpindahan minimum yaitu wilayah tanjung pinang dengan nilai perpindahan 0,017903 $\mathrm{m}$ dan kondisi tanah keras. Untuk daerah kontur gempa tinggi yaitu aceh dan padang secara umum memiliki respons peripindahan yang lebih besar dibandingkan dengan daerah tanjung pinang dan pekanbaru. Hal ini mengindikasikan bahwa jenis tanah dan percepatan tanah terhadap gempa menentukan respons struktur pada jembatan tersebut. Sedangkan perpindahan maksimum dan minimum arah y dapat dilihat pada gambar 6 berikut ini.

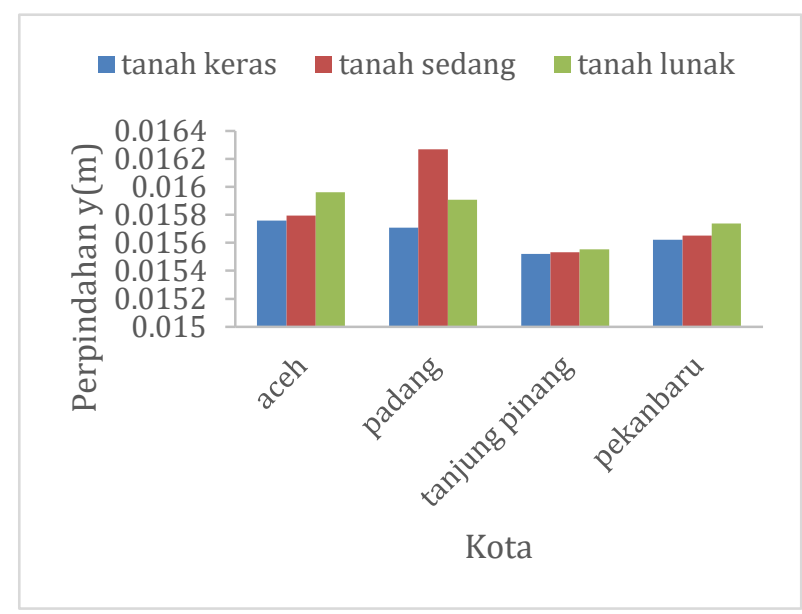

Gambar 6. Perpindahan Arah Y Pada Titik Pengamatan

Nilai perpindahan maksimum arah y terdapat di wilayah padang dengan kondisi tanah sedang dan nilai perpindahannya yaitu sebesar 0,016267 $\mathrm{m}$. Dan nilai perpindahan minimum arah y terdapat di wilayah tanjung pinang dengan kondisi tanah keras dan besar perpindahan yang terjadi yaitu sebesar 0,01552 m. Untuk daerah kontur gempa tinggi yaitu aceh dan padang secara umum memiliki respons peripindahan yang lebih besar dibandingkan dengan daerah tanjung pinang dan pekanbaru. Hal ini mengindikasikan bahwa jenis tanah dan percepatan tanah terhadap gempa menentukan respons struktur pada jembatan tersebut.

Percepatan pada arah $\mathrm{x}$ dan $\mathrm{y}$ dapat dilihat pada gambar dibawah ini.

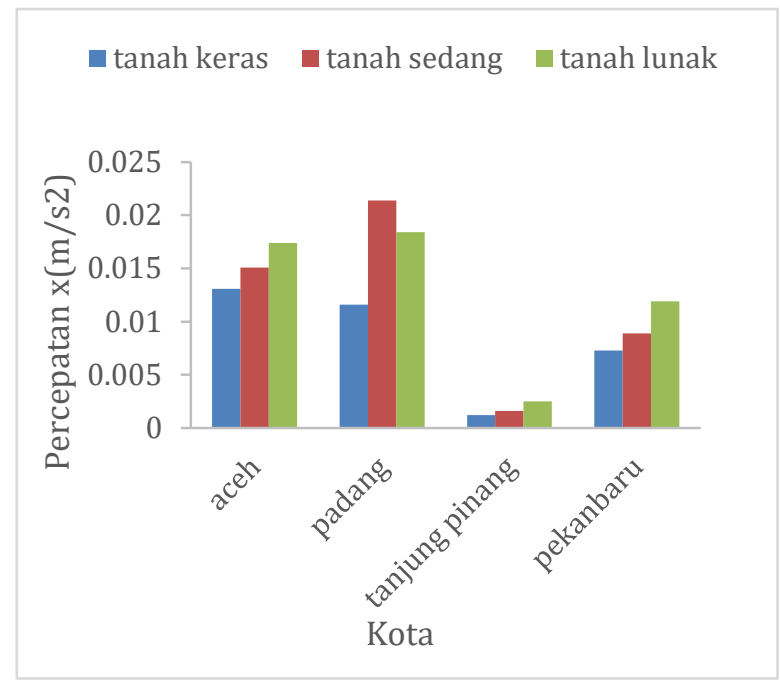

Gambar 7. Percepatan Arah X Pada Titik Pengamatan

Berdasarkan gambar 7 nilai percepatan arah $\mathrm{x}$ maksimum terjadi pada wilayah padang dengan nilai percepatan sebesar 0,0235 m dan kondisi tanah sedang. Sedangkan nilai percepatan minimum arah $\mathrm{x}$ terdapat diwilayah tanjung pinang dengan kondisi tanah keras. Dan nilai percepatan nya sebesar $0,0012 \mathrm{~m}$. Untuk daerah kontur gempa tinggi yaitu aceh dan padang secara umum memiliki respons peripindahan yang lebih besar dibandingkan dengan daerah tanjung pinang dan pekanbaru. Hal ini mengindikasikan bahwa jenis tanah dan percepatan tanah terhadap gempa menentukan respons struktur pada jembatan tersebut.

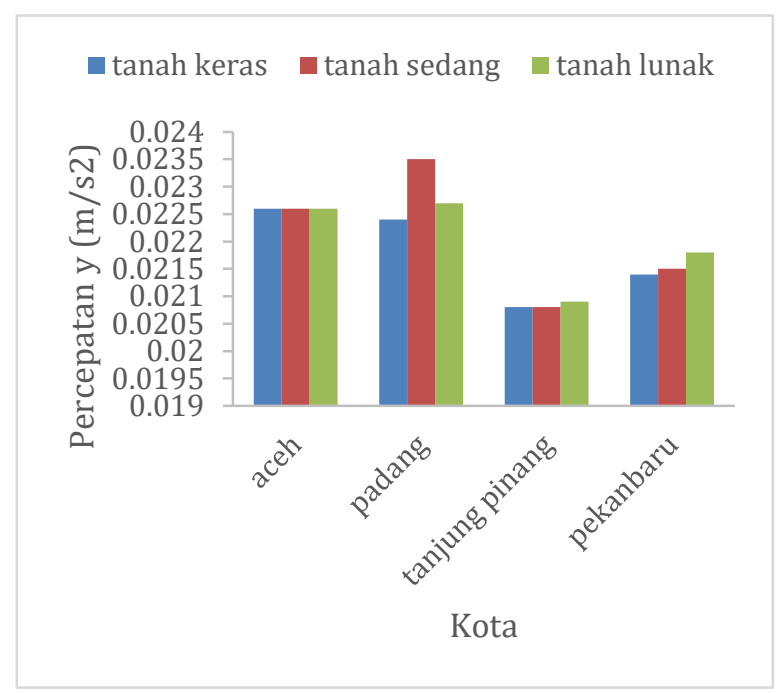

Gambar 8. Percepatan Arah Y Pada Titik Pengamatan 
Pada arah $\mathrm{Y}$ pada titik pengamatan menghasilkan nilai percepatan maksimum arah y terdapat pada wilayah padang, kondisi tanah sedang dengan nilai percepatan 0,0235 m. Dan nilai percepatan minimum arah y yaitu wilayah tanjung pinang dengan kondisi tanah keras dan tanah sedang. Dan nilai percepatannya yaitu sebesar 0,0208 m. Sedangkan wilayah aceh dengan nilai percepatan sama baik dengan kondisi tanah keras, tanah sedang dan tanah lunak. Untuk daerah konturrgempa tinggi yaitu aceh dan padang secara umum memiliki respons peripindahan yang lebih besar dibandingkan dengan daerah tanjung pinang dan pekanbaru. Hal ini mengindikasikan bahwa jenis tanah dan percepatan tanah terhadap gempa menentukan respons struktur pada jembatan tersebut.

\section{KESIMPULAN}

Kesimpulan dari penelitian ini antara lain adalah: (a) nilai perpindahan dan percepatan maksimum untuk suatu lokasi untuk daerah Aceh, Padang, Tanjung Pinang dan Pekanbaru diperngaruhi oleh jenis tanah pada lokasi tersebut. Nilai Maksimum terjadi pada tanah sedang dan tanah Lunak. Sedangkan nilai minimum terjadi pada tanah keras; (b) respons Struktur perpindahan dan percepatan terbesar terjadi di Padang yaitu untuk nilai perpindahan sebesar 0,016267 $\mathrm{m}$ dan percepatan sebesar $0,0235 \mathrm{~m}$. Sedangkan untuk nilai respons struktur terkecil; (c) respons struktur terkecil terjadi di kota Tanjung Pinang yaitu perpindahan sebesar 0,01552 $\mathrm{m}$ dan percepatannya sebesar 0,0208 m.

\section{UCAPAN TERIMA KASIH}

Terima kasih kepada Kemenristek Dikti yang telah mendukung melalui program hibah Penelitian Kerja Sama Perguruan Tinggi Tahun 2019-2020. Serta Prodi Teknik Sipil Universitas Lancang Kuning.

\section{REFERENSI}

[1] T. BMS, "Bridge Management System," p. 1, 1993.

[2] W. Apriani, S. W. Megasari, W. Alrisa, and P. Loka, "Penilaian Jembatan Rangka Baja Transfield Australia Dengan Metode Fracture Critical Member ( Studi Kasus: Jembatan Siak 2 Pekanbaru )," no. September, pp. 18-19, 2018.

[3] R. Suryanita and A. Adnan, "Application of Neural Networks in Bridge Health Prediction based on Acceleration and Displacement Data Domain Application of Neural Networks in Bridge Health Prediction based on Acceleration and Displacement Data Domain," vol. I, no. February 2016, pp. 4-9, 2013.
[4] Mardiyono, R. Suryanita, and A. Adnan, "Intelligent monitoring system on prediction of building damage index using neural-network," TELKOMNIKA (Telecommunication Comput. Electron. Control., vol. 10, no. 1, pp. 155-164, 2012.

[5] R. Suryanita, "The Application of Artificial Neural Networks in Predicting Structural Response of Multistory Building in The Region of Sumatra Island," KnE Eng., vol. 1, no. 2015, pp. 1-6, 2016.

[6] R. Suryanita, H. Maizir, and H. Jingga, "Prediction of Structural Response due to Earthquake Load using Artificial Neural Networks," Int. Conf. Eng. Technol. Comput. Basic Appl. Sci. ECBA, 2016, Osaka, Japan, vol. 182, no. 4, 2016.

[7] Mardiyono, R. Suryanita, and A. Adnan, "Intelligent monitoring system on prediction of building damage index using neural-network," TELKOMNIKA (Telecommunication Comput. Electron. Control., vol. 10, no. 1, pp. 155-164, 2012. [8] J. Brownjohn, "Structural Health Monitoring of the Tamar Bridge," Vce.At, pp. 465-490, 1961.

[9] J.-J. Lee and C.-B. Yun, "Damage localization for bridges using probabilistic neural networks," KSCE J. Civ. Eng., vol. 11, no. 2, pp. 111-120, 2008.

[10] S. Tohidi and Y. Sharifi, "A new predictive model for restrained distortional buckling strength of half-through bridge girders using artificial neural network," KSCE J. Civ. Eng., vol. 20, no. 4, pp. 1392-1403, 2016.

[11] P. H. a Nababan, "Structural Health Monitoring System Alat Bantu Mempertahankan Usia Teknis Jembatan," Constr. Maint. main span Suramadu Bridg., pp. 1-2, 2008.

[12] N. M. Apaydin, A. C. Zulfikar, and H. Alcik, "Introduction of Bogazici Suspension Bridge Structural Health Monitoring System," 15th World Conf. Earthq. Eng., 2012.

[13] M. Mehrjoo, N. Khaji, H. Moharrami, and A. Bahreininejad, "Damage detection of truss bridge joints using Artificial Neural Networks," Expert Syst. Appl., vol. 35, no. 3, pp. 1122-1131, 2008.

[14] Z. Chen, X. Zhou, X. Wang, L. Dong, and Y. Qian, "Deployment of a smart structural health monitoring system for long-span arch bridges: A review and a case study," Sensors (Switzerland), vol. 17, no. 9, 2017.

[15] D. S. Shan, P. Yan, and Z. H. Wang, "Intelligent Health Monitoring System for a Railway Cable-Stayed Bridge," Adv. Mater. Res., vol. 148-149, no. 1, pp. 1390-1393, 2010.

[16] N. D. Lagaros and M. Papadrakakis, "Neural network based prediction schemes of the non- 
linear seismic response of 3D buildings," Adv. Eng. Softw., vol. 44, no. 1, pp. 92-115, 2012.

[17] D. Shyam, G. B. L. Chowdary, and D. R. Mahapatra, "Structural Damage Identification Using Artificial Neural Network and Synthetic data."

[18] S. Ok, W. Son, and Y. M. Lim, "A study of the use of artificial neural networks to estimate dynamic displacements due to dynamic loads in bridges," J. Phys. Conf. Ser., vol. 382, no. 1, 2012.

[19] A. S. Fahmy, M. E. T. El-Madawy, and Y. Atef Gobran, "Using artificial neural networks in the design of orthotropic bridge decks," Alexandria Eng. J., vol. 55, no. 4, pp. 3195-3203, 2016.

[20] S. Kim, "Experimental investigation of local damage detection on a 1/15 scale model of a suspension bridge deck," KSCE J. Civ. Eng., vol. 7, no. 4, pp. 461-468, 2008.

[21] W. F. Darmawan, R. Suryanita, and Z. Djauhari, "Evaluasi Kesehatan Struktur Bangunan berdasarkan Respon Dinamik Berbasiskan Data Akselerometer," Media Komun. Tek. Sipil, vol. 23, no. 2, p. 142, 2017.

[22] R. Suryanita, "Prediksi Kerusakan Model Jembatan Beton Bertulang Berdasarkan Mutu Beton dengan Metode Jaringan Saraf Tiruan," no. November, $\quad$ pp. 368-375, 2015.
[23] A. C. Neves, I. González, J. Leander, and R. Karoumi, "Structural health monitoring of bridges: a model-free ANN-based approach to damage detection," J. Civ. Struct. Heal. Monit., vol. 7, no. 5, pp. 689-702, Nov. 2017.

[24] M. Lydon, S. E. Taylor, D. Robinson, A. Mufti, and E. J. O. Brien, "Recent developments in bridge weigh in motion (B-WIM)," J. Civ. Struct. Heal. Monit., vol. 6, no. 1, pp. 69-81, 2016.

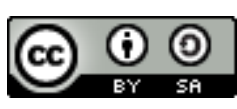

This is an open access article which means that all content is freely available without charge to the user or his/her institution. Jurnal Saintis allows the author(s) to hold the copyright without restriction. The copyright in the text of individual rticles (including research article, opinion articles, and abstracts) is the property of their respective authors distriuted under the terms of the Creative Commons Attribution-ShareAlike 4.0 International License

(http://creativecommons.org/licenses/by-

sa/4.0/) which permits unrestricted use, distribution, and reproduction in any medium. Users are allowed to read, download, copy, distribute, search, or link to full-text articles in this journal without asking by giving appropriate credit, provide a link to the license, and indicate if changes were made. 
This page is intentionally blank 